УДК 7.03(517.3) + 7.04:24 + 391(517.3) + Mongolian University of Science and Technology $+94(517.3)$

\title{
ICONOGRAPHY OF THE WHITE OLD MAN - TSAGAAN EBUGEN'S IMAGE IN MONGOLIAN ETHNIC ART
}

This article attempts to compare written primary sources, such as sutras dedicated to Tsagaan Ebugen, with a range of different visual materials, and take into consideration the unity of cultural and artistic aspects. Based on different art materials collected by the author including fifty-four Mongolian, eighteen Kalmyk, and twenty-one Buryat images, the author shows the features and aspects of the iconography of the image based on the details of clothing. The article provides a detailed analysis of the whole complex of iconographic elements included in the image of Tsagaan Ebugen, such as face, hair, figure, clothes, shoes, and hats. The purpose of the article is to present the results of the analysis of art materials associated with the image of the White Old Man as well as to identify the most stable and persistent iconographic features of the image. The pictorial iconography of Tsagaan Ebugen reflects the complex relationship between the ancient chthonic and Buddhist principles. As a result of the study, it is demonstated that traditional elements of clothing are preserved in the image of the lord of the earth and water of the White Old Man, and only ten percent of all images collected by the author are an exception and have other elements of clothing details that appeared due to the historical and religious influence in the region.

Ke y w ords: Mongolian art; Lord of the earth and water; Mongolian traditional clothes; religious art; archaic image; Buddhist art; Kalmyk art; Buryat art

F o r c i t a t i o n: Batchuluun, S. (2021). Iconography of the White Old Man - Tsagaan Ebugen's Image in Mongolian Ethnic Art. Izvestiya Uralskogo federalnogo universiteta. Seriya 2: Gumanitarnye nauki, 23(4), 23-31. https://doi.org/10.15826/izv2.2021.23.4.064

Submitted: 01.06.2021

Accepted: 12.10.2021

Сэргэлэн Батчулуун

Монгольский университет науки и технологии

Улан-Батор, Монголия

\section{ИКОНОГРАФИЯ БЕЛОГО СТАРЦА - ИЗОБРАЖЕНИЕ ЦАГААНА ЭБУГЕНА В МОНГОЛЬСКОМ ЭТНИЧЕСКОМ ИСКУССТВЕ}

В данной статье автором была предпринята попытка сопоставить известные письменные первоисточники, такие как сутры, посвященные Цагаану Эбугену, или Владыке земли и воды Белому Старцу, с различными визуальными материалами, 
а также принять во внимание единство культурных и художественных аспектов его изображения. Так, на основе собранных автором различных художественных материалов, которые включают в себя 54 монгольских, 18 калмыцких, а также 21 бурятское изображение Цагаана Эбугена, автор выявляет особенности иконографии образа Белого Старца с учетом деталей его одежды. В данной статье подробно рассматривается весь комплекс иконографических элементов, который включает в себя изображение Белого Старца: автор статьи анализирует лицо Цагаана Эбугена, как представлены его волосы, изображена его фигура, как переданы его одежда и обувь, а также обращает внимание на головные уборы. Цель данной статьи заключается в том, чтобы представить результаты анализа отобранных автором визуальных материалов, которые так или иначе связаны с образом Белого Старца, а также в том, чтобы раскрыть наиболее устойчивые иконографические особенности его изображения. В изобразительной иконографии Цагаана Эбугена нашли отражение сложные взаимоотношения древнего хтонического и буддийского начал. В ходе исследования было выявлено, что в образе Владыки земли и воды Белого Старца присутствуют в основном элементы традиционной одежды, и только около 10 \% всех собранных автором изображений являются исключением и имеют другие детали одежды, что может быть обусловлено различными историческими событиями и религиозным влиянием в регионе.

К л ю ч е в ы е с л о в а: монгольское искусство; Владыка земли и воды; монгольская традиционная одежда; религиозное искусство; архаичный образ; буддийское искусство; калмыцкое искусство; бурятское искусство

Ц и т и р о в а н и е: Batchuluun S. Iconography of the White Old Man - Tsagaan Ebugen's Image in Mongolian Ethnic Art // Известия Уральского федерального университета. Сер. 2: Гуманитарные науки. 2021. Т. 23, № 4. С. 23-31. https://doi. org/10.15826/izv2.2021.23.4.064

Поступила в редакцию: 01.06.2021 Принята к печати: 12.10.2021

A period of active scholarly generalizations and systematizations in oriental studies started in the twentieth century. It led to a deepening specialization culture of a particular eastern region of people, according to their interest in religious issues, philosophy, philology, history, and art within Mongolian studies as part of Oriental studies. An important place in the development of scholarly systematization of private and public collections was played by active museums and exhibition activities, which required the completeness of attribution of the exhibited works.

The scholarly study of Tsagaan Ebugen began between the early twentieth and twenty-first centuries. First, it is necessary to highlight research in the framework of historical, mythological, historical-religious studies and ethnographic and cultural contexts. Based on the functions, properties, and characteristics of Tsagaan Ebugen, most researchers look for the origins of this image in shamanism (B. Sodnom [Sodnom, p. 391], E. P. Bakaeva [Bakaeva, p. 8], S. G. Batyreva [Batyreva, 2011, p. 33], N. L. Zhukovskaya [Zhukovskaya, p. 64], S. Yu. Neklyudov [Neklyudov, p. 82], W. Heissig [Heissig, p. 127] et al.). French scholar A. Mostaert describes the image 
of the White Man in the framework of the religious beliefs of the Ordo Mongols and traces him back to shamanistic cults [Mostaert, p. 110]. German researcher W. Heissig [Heissig, p.127] calls Tsagaan Ebugen a pseudo-Buddhist deity, thereby also leaning towards his shamanic roots. Zhukovskaya [Zhukovskaya, p. 33] relates the cult of the Tsagaan Ebugen to the cult of nature, thereby pushing it into the early forms of religion. The author's research shows that the image of the Master of the Earth has deep roots going back to the ancient picture of the world and is closely intertwined with the nomadic way of life of the Mongols, which explains the different points of view of scholars about the origins of the image itself.

The study of the pictorial iconography of Tsagaan Ebugen is associated with a number of difficulties. The author was unable to find pre-Buddhist and Buddhist written iconographic or iconometric sources, which would contain information about the system of rules for depicting the White Old Man and the time of appearance of his first canonical images. Due to the impersonal nature of the work of medieval masters, poor preservation of things, loss of information about the place of their production or original location, the works presented by the author dedicated to Tsagaan Ebugen also do not provide sufficient scholarly grounds for an accurate determination of the time of the first iconographic samples.

Gerasimova makes an assumption that the iconographic matrices of the early periods of Buddhist and Northern Buddhist assimilation of the Tsagaan Ebugen image by Mongolian natives date back at least to the twelfth or thirteenth centuries, to the time of the second wave of Buddhism. She explains this by the fact that the image of Tsagaan Ebugen, which grew out of the cult of the oldest family patron saint "ancestor," could not help but be included and preserved as an obligatory, necessary deity in the most traditional household family cult. Gerasimova writes: "Sagaan ubgen is the same collective concept as Buural babai ('gray-haired ancestor father') or Deed baabai ('supreme father')"; it has merged the symbolism of the cult of ancestors and the cult of nature [Gerasimova, p. 162]. The images of the White Old Man, she emphasizes, could not help but be in the home shrine among the multitude of "icons", ongons, corresponding to the strictly regulated space of the yurt: suspended, free-standing, leaning, etc. In particular, Plano Carpini writes about this. In nomadic life, images inevitably quickly deteriorated. Dilapidated images were usually not destroyed, but updated by copying. Therefore, the images of family patrons could preserve the early traditions of the pictorial embodiment of the Mongolian cult of Tsagaan Ebugen, concludes Gerasimova. The opinion about the early iconographic origins of the Tsagaan Ebugen image is not shared by other researchers. According to S.V. Ivanov, shamanism did not know images of "high rank" deities [Ivanov, p. 834]. Ongons of shamanism usually depicted specific spirits: hearth fire, river water, yurt doors, individual places of the surrounding nature, etc. In this case, the time of its canonization by Buddhism can be considered the only reference date, in a sense exactly fixing the emergence of the iconography of Tsagaan Ebugen.

The iconography of Tsagaan Ebugen is directly related to both his genesis and his position in the pantheon of the deities of northern Buddhism that exist 
in the Mongolian world. This position in the strict hierarchical system of the Buddhist pantheon determines a number of iconographic features of the deity, as well as its place in the regulated space of temple complexes.

The iconographic foundations of the image of Tsagaan Ebugen cover the entire complex of its features. The systemic characteristics, as evidenced by the sutras, include his description as an old man who has reached a venerable age ${ }^{1}$, "with very gray hair and beard," "white as snow," "like a white desire with a beard and hair," and also as a "wise old man, who became like a perfect Universe", as the Universal wise White Old Man [Bawden, p. 70]. In sculpture, paintings, tankas, and works of arts and crafts, Tsagaan Ebugen is usually depicted as a man of venerable age with deep wrinkles on his face, with white hair, white eyebrows, and a white mustache and beard (Fig. 1, 3). The iconometric height of the skull of Tsagaan Ebugen in its facial part to the edge of the scalp is very large. In the pictorial tradition, plastically, it is most often interpreted as the head of a bald old man, with white hair on the back of the head. However, there are Kalmykia's images, more often tanks, in which the old man's head is crowned with a high hairstyle in the form of a bun of hair gathered by a "turret" at the top. In Mongolia, we found a unique sculpture with the same hairstyle. This also retains the stable, iconometrically high proportions of the head inherent in Tsagaan Ebugen. In the symbolism of Buddhism, both options can be understood as an expres-

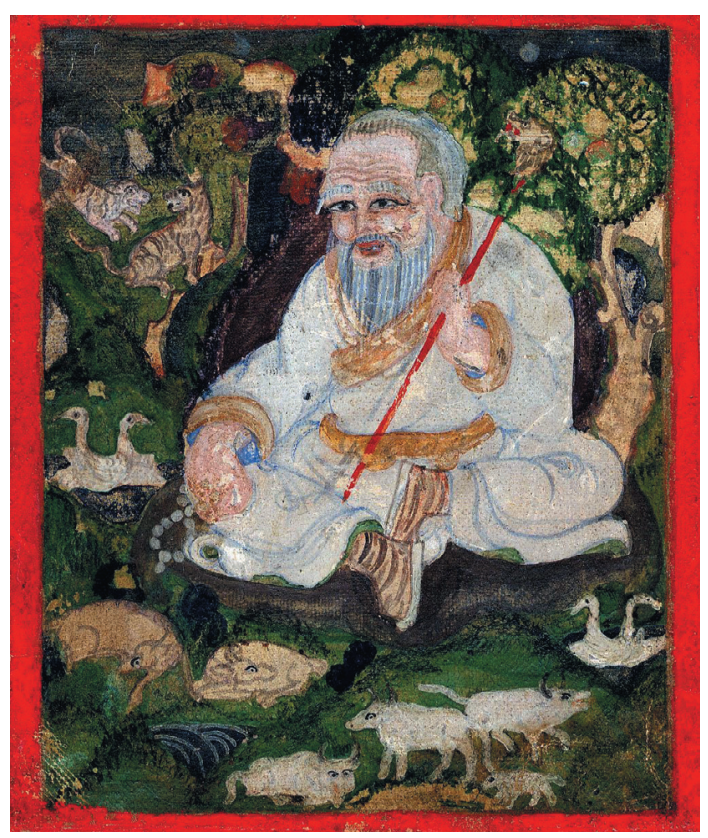

Fig. 1. Mineral color, primed silk. $10 \times 8.5$.

Second half of the $17^{\text {th }}$ century. Private collection

${ }^{1}$ White Old Man's "Tserendug sutra”. 
sion of the parietal bulge or ushnishi, denoting a high level of enlightenment achieved, the highest measure of knowledge and wisdom. "Old age, wisdom" says an old Mongolian proverb. It is interesting that in the history of the Mongolian fine art an early human image with clearly marked parietal convexity is preserved. These are two figures of petroglyphs published in a thematic catalog, compiled by such eminent scholars as D. Luvsandamba, D. Tseveendorj, etc. On the large stone log cabins of the Zavkhan Tsetsen-uul somon province, dating from between the sixth and eighth centuries, a man is depicted, whose head in its upper part has an oval-diamond-shaped protrusion [Luvsandamba, p. 136]. One of the figures has a circle inscribed in this ledge. Perhaps the image of "Ushnishi" came to Mongolia with the first wave of Buddhism. Ethnologists say that until now, in Mongolia a person with a high forehead is considered to be the owner of a great mind (Fig. 2, 3).

An important iconographic feature of the White Old Man is his clothing. All sutras describe Tsagaan Ebugen dressed in white Delhi, in Delhi "the color of pearls". The works of art reviewed in this article confirm the immutability of this element of clothing (Fig. 1, 2). Tsagaan Ebugen is depicted, as a rule, in the Mongolian national Delhi-robe, which has a clasp on the right, with both shoulders covered in some images. There are images when a dressing gown with a swing cut with a straight collar is worn over the Delhi. Occasionally, a cloak is thrown over the shoulders of Tsagaan

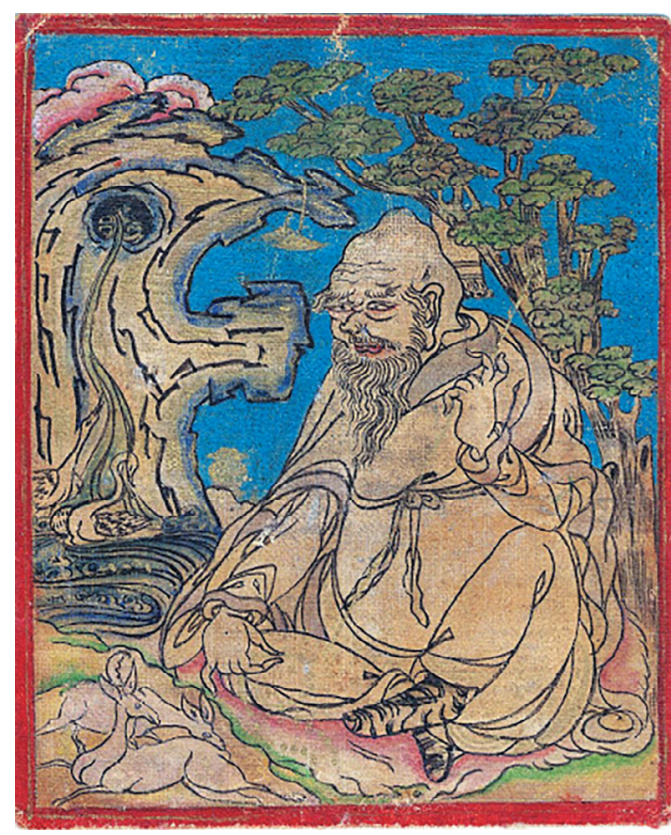

Fig. 2. Wood; carving, painting. $8.5 \times 16 \times 6.5$. Late $18^{\text {th }}$ century. Mongolia, Ulan Bator. Private collection

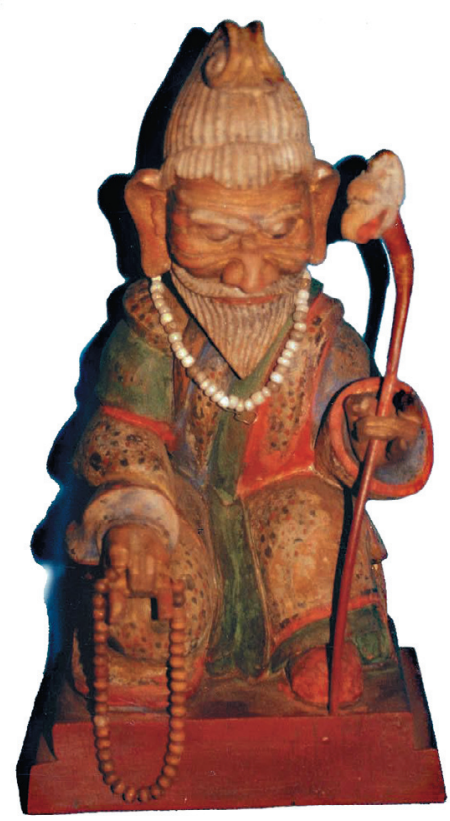

Fig. 3. Primed canvas, mineral paints. $11 \times 9$. $18^{\text {th }}$ century. Mongolia, Ulan Bator. Private collection 
Ebugen (Fig. 2, 3). The origins of this piece of clothing can be associated with both Mongolian household clothing and the clothing of the clergy. So, in Mongolia, in bad weather, they wore a raincoat (tsuv), which was the same in cut as a regular Delhi, but it did not have a liner, and there was a cut from the waist almost to the bottom. Tsur was comfortable in that the rider on horseback, tucking the hem of his cloak, was well sheltered from the rain and wind. The monks' clothing also included a semblance of an outer robe. During the service, lamas wear another red or yellow cape lined with a collar (nomin khuvtsas) over their monastic clothes and orkhimji. An exception is the depiction of Tsagaan Ebugen when his upper body is naked. Thus, in a sculpture from a private collection Tsagaan Ebugen is represented in the image of the ascetic Milaraba. In rare cases, there is an image of Tsagaan Ebugen in the clothes of a Chinese dignitary, in a dressing gown with a straight collar and sleeves that extend downward. Another detail of the White Old Man's clothing is the shoulder pads with the uulen hee ornament, symbolizing goodwill and longevity. Shoulders are a characteristic piece of clothing for a warrior and cultural hero. The belt is a symbolically significant detail of the White Old Man's clothing, which is mentioned in the sutras. "The precious belt passing through the three worlds" is mentioned in the sutra "Gazar usnii ezen Tsagaan ovgoniy tahiliin san" (sutra "Incense for the innumerable White Old Man, lord of lands and waters"); "Passing through the three worlds with a precious belt" says in the sutras "Gazar usnii ezen Tsagaan ovgoniy zaslyn sudar"2 and "Tsagaan ovgoniy san sudar orshvoy" (sutra Tsagaan Ebugen). Tsagaan Ebugen is called "girded with a precious belt" in the sutra "Gazryn ezdiig nomhotgogch Tsagaan ovgon "Tserendugiin" tangariin sudar orshvoy"3. Thus, in all sutras, a belt is mentioned a kind of thread that connects different worlds in the structure of the universe, "ours" and that of "aliens", "the other" space, a source of vitality. In the pictorial tradition, a belt is almost always visible on Tsagaan Ebugen. Sometimes it is tied in the form of a knot in a complex pattern, as if emphasizing the strength of the connection between the three worlds. The available texts do not contain information about the color, material, or the shape of the belt. Works of fine art show that the belt is usually a Mongolian sash: green, yellow, red, and blue.

There is no mention of the White Old Man's paridhana ('shoe') in the sutras. In the materials of the catalog, the Master of the Earth is usually depicted in leather boots of the Mongolian cut - traditional black shoes. According to L. L. Viktorova, Mongolian boots are similar to the boots of Tibetans, Buryats and Kalmyks [Viktorova, p. 46]. An important design feature of Mongolian boots is that their vamps and bootlegs are cut from two symmetrical halves. The shafts cover the entire shank and are the same width at the top and bottom. The vamp is rigid and sewn tightly to the bootleg. The sole is thick, rigid, with a felt pad, the hard toe is bent up. The sole is sewn onto the vamp with welt; there are no gathers in the vamp. Almost all the design features of Mongolian boots described above are guessed in the images

\footnotetext{
2 "sutra "Master of the Earth and Water Tsagaan Ebugen".

3 "sutra "Oath of Tsagaan Ebugen "Tserentsug" of the pacifier of the landowners".
} 
of the White Old Man (Fig. 3). There are also soft boots imitating tiger skin, which will be described in more detail later (Fig. 1,2). Often Tsagaan Ebugen is shod in soft shoes, sometimes with an uulen hee ornament (Fig. 3). Images of the White Old Man being barefoot are extremely rare; there are only two of them in the catalog.

One of the most important details of the Mongolian men's clothing, along with a belt, is a hat. There is no mention of the headdress of the White Old Man in the sutras, but in the pictorial tradition the headdresses of Tsagaan Ebugen are diverse. They have a strong Mongolian coloration. In a number of images Tsagaan Ebugen has a har khilen on his head, a headdress usually worn by high-ranking officials. The traditional headdress, modernized during the Manchu expansion, is a high cone-shaped pointed "head" with black "brims" bent upwards. The cap is crowned with a "ball". This form certainly goes back to the model of the world. The conical shape is associated with the Mountain. The ball on top, as noted by D. Maidar, is a symbol of the sun, the ancient deity of the Mongols, who considered themselves the people of the sun and the moon. A red tassel descending from under the ball, and a cone-shaped top of the headdress, stitched with thirty-two columns symbolize the rays of the sun, warming the hearts of the "people of thirty-two tribes". "The black circle at the base of the cap" (field), as D. Maidar writes, meant mourning for the once lost independence. The back open space of the cap, where the double ribbon is laid, is a symbol of the joy of liberation. The headdress of Tsagaan Ebugen could also be the toortsog, which repeats the shape of the yurt, which also personifies the model of the Universe. In the works created in Buryatia, Kalmykia, the toortsog end has a characteristic dark blue, black color, on which orange, yellow, and red ornaments stand out. In addition to the Mongolian headdress, the White Old Man has Chinese hats of a secular titled person, which testifies to the above-mentioned Chinese influences on the iconography of Tsagaan Ebugen, traced from the eighteenth century. Thus, the features of the ethnic environment or social hierarchy are reflected in the forms and decorative elements of the hats. A hat in the traditional culture of Mongolia is a particularly revered piece of costume. Even when removed from the head, it was placed in a strictly regulated space of the yurt: horizontally, in the northern male part of it; vertically, - not below the bed level. The hat could not be touched by strangers. Receiving each new rank and blessing from Bogd-gegen took place only with a headdress. Likewise, there are other key moments in the life of the Mongols, such as: matchmaking a bride, giving a hadak, and accepting it. The introduction of the headdress into the pictorial canon was obviously not accidental. This undoubtedly strengthened the world-modeling principle centered in the image of Tsagaan Ebugen.

Among the images collected by the author, of particular interest is the Buryat tanka with a non-canonical headdress, dating back to the end of the twentieth century. Between the early nineteenth and twentieth centuries, the White Old Man was depicted crowned. The five-petalled lotus hat symbolizes the "five families of Buddhas" and the owner's belonging to the lotus family of Buddha Amitabha. At the top of the crown, there is a vajra that represents the realization of Buddhanature, a state of consciousness beyond duality. A rare iconographic scheme goes back 
to the iconography of the crowned Buddha. The latter is quite common. In the context of our work, the sculpture of the crowned Buddha from the Regional Museum of Kalmykia (inventory number of 1918) is of interest. It is known that this sculpture existed for a long time on the territory of Kalmykia, which, according to the research of S. G. Batyreva [Batyreva, 2002, p. 172], had close contacts with Buryatia.

The appearance of the crown in the depiction of Tsagaan Ebugen can be explained by the development of his iconography: the Buryat tanka dates from between the late nineteenth and early twentieth centuries. At this time, freeing itself from Manchu colonization, Mongolia gained independence. Bogdo Khan, a leader who unites spiritual and secular power in one person was head of state at the time. A small, exhausted country defended independence from its powerful neighbors in every way available to it. An important support here was the appeal to their ancestral roots. The image of Tsagaan Ebugen became one of the most popular. As Ts. B. Badmajapov [Badmajapov, p. 154] notes, it was during this period that a number of changes took place in the iconography of Tsagaan Ebugen. His compositions grow enormously, which will be shown later. It is also important to mention here that among the new iconographic elements in the upper left corner in the tanks of the White Old Man, Buddha Amitayus appears, who is often called the "crowned Buddha". We can assume that in the image of the crowned Tsagaan Ebugen, through the most important symbolic detail, Amitayus himself gets the opportunity to emit. So Tsagaan Ebugen rises and refines, becoming a crowned deity.

The iconographic foundations of the image of Tsagaan Ebugen are quite clear and definite, while they are rich and diverse. The latter can be explained by the multiplicity of layers that form the image, whose roots go back to ancient times. Iconography here is not reduced to a strict canon-scheme or canon-template. It is a kind of synthesis of centuries-old living life observations and canonical symbolism, preserving that warmth and the closeness of deity and man, which distinguishes either early, or very developed, sophisticated forms of religious consciousness.

The pictorial iconography of Tsagaan Ebugen, on the one hand, relies on written canonical sources and follows them; on the other hand, he freely processes iconographic texts, for the image of the Master of the Earth maintains a stable connection with the phenomenon of folk religion. In the culture of the Mongolian people, the image of the White Old Man remains one of the most popular folklore images. Even today he appears in many key moments of life, being the patron saint of an entire nation of Mongols, Kalmyks, Buryats. As the analysis shows, its leading place can be explained by the fact that the cult of Tsagaan Ebugen is a kind of combination of the cult of Nature and ethnic forms of the cult of ancestors. In conclusion of the article, I would like to note that the iconographic phenomenon of Tsagaan Ebugen in the space of the Mongolian area refers to living developing phenomena. 


\section{References}

Badmazhapov, Ts. B. (Comp.). (1995). Buddijskaia zhivopis’ Buryatii [Buddhist Painting of Buryatia]. Ulan-Ude: Nyutag.

Bakaeva, E. P. (2011). Sakralnye kody kul'tury Kalmykov [Sacred Codes of Kalmyk Culture]. Elista: IKKIAT.

Batyreva, S. G (2011). Kalmytskoe izobrazitel'noe iskusstvo XIX - nachala XX vo.: Opyt istorikokulturnoi rekonstruktsii [Kalmyk Fine Arts of the $19^{\text {th }}-$ Early $20^{\text {th }}$ Centuries. An Attempt at Historical and Cultural Reconstruction] (habilitation dissertation abstract). Research Institute of Theory and History of Fine Arts of the Russian Academy of Sciences, Moscow.

Batyreva, S. G. (2002). K voprosu regionalnoi spetsifiki ikonografii Belogo startsa (mongolooiratskie i buriatskie paralleli v zhivopisi buddizma) [On the Regional Specificity of the Iconography of the White Old Man (Mongol-Oirat and Buryat Parallels in the Painting of Buddhism)]. In R. B. Rybakov (Ed.), E. V. Boikova, M. I. Golman, V. V. Graivoronskii, A. S. Zheleznyakov, \& A. D. Tsendina; A. S. Zheleznyakov (Comp.), VIII Mezhdunarodnyi kongress mongolovedov: doklady rossiiskoi delegatsii [VIII International Congress of Specialists in Mongolian Studies: Reports of the Russian Delegation] (pp. 171-177). Moscow: Gumanitarij.

Bawden, C. R. (1958). Two Mongol Texts Concerning Obo-worhip. Oriens Extremus, 5(1), 23-41.

Gerasimova, M. K. (1983). Lamaizm v Buryatii XVIII - nachala XX vv. Struktura i sotsialnaia rol' $v$ kul'tovoi sisteme [Lamaism in Buryatia from the $18^{\text {th }}$ to the Early $20^{\text {th }}$ Centuries. Structure and Social Role in the Belief System]. Novosibirsk: Nauka.

Heissig, W. (1966). Les religions du Tibet et de la Mongolie. Paris: Payot.

Ivanov, S. V. (1954). Materialy po izobrazitel'nomu iskusstvu narodov Sibiri XIX - nachala XX v. Suzhetnyi risunok $i$ drugie vidy izobrazhenii na ploskosti [Materials on the Fine Arts of the People of Siberia in the $19^{\text {th }}-$ Early $20^{\text {th }}$ Centuries: Plot Drawing and Other Types of Flat Images]. Moscow: USSR Academy of Sciences Publishing.

Luvsandamba, D. (1999). Mongol nutag dakh tuuh soeliin dursgal [Historical and Cultural Monuments in Mongolia]. Ulaanbaatar: Mongolyn Khủmủủnlėgiı̆n Ukhaany Akademi.

Mostaert, A. (1941). Dictionaire Ordos (Vol. 1). Monumenta Seria Monographs, V. Peking: Catholic University.

Neklyudov, S. Yu. (1984). Geroucheskii epos mongol'skih narodov. Ustnye i literaturnye traditsii [The Heroic Epic of the Mongolian Peoples. Oral and Literary Traditions]. Moscow: Nauka.

Sodnom, B. (1999). Har buugiin duudlagiin tukhai [About the Prayer of the Black Shamani]. Mongol sudlal Ulaanbaatar.

Viktorova, L. L. (1980). Mongoly. Proishozhdenie naroda i istoki kul'tury [Mongols. The Origin of the People and the Origins of Culture]. Moscow: Nauka.

Zhukovskaya, N. L. (1977). Lamaism i rannie formy religii [Lamaism and the Early Forms of Religion]. Moscow: Nauka.

\section{Batchuluun, Sergelen Sharnuud}

PhD (Art History), Associate Professor

Design Department

Mongolian University of Science

and Technology

34, Baga Toyruu St., 14191 Ulan Bator,

Mongolia

Email: b.sergelen@must.edu.mn

https://orcid.org/0000-0002-0157-6437

\section{Батчулуун Сэргэлэн Шарнууд}

кандидат искусствоведения, доцент департамента дизайна

Монгольский университет науки и технологии

14191, Монголия, Улан-Батор, ул. Бага тойруу, 34

E-mail: b.sergelen@must.edu.mn 